\title{
The Role of Political Communication in Anticipating Social Conflicts Based on the Government Policy in East Java
}

\author{
Rr. Nanik Setyowati \\ Department of Pancasila and Civic Education \\ UniversitasNegeri Surabaya \\ Surabaya,Indonesia \\ naniksetyowati@unesa.ac.id
}

\author{
FX.SriSadewo \\ Department of Social Studies \\ UniversitasNegeri Surabaya \\ Surabaya,Indonesia \\ fsadewo@unesa.ac.id
}

\author{
Martinus Legowo \\ Department of Social Studies \\ UniversitasNegeri Surabaya \\ Surabaya,Indonesia \\ marleg@unesa.ac.id
}

\begin{abstract}
Based on the sociological perspective, the results concluded that the policy issued by the government that was originally to overcome social conflicts in the community, actually raises a new problem. This shows the need for the role of political communication. Political communication is a process of transferring messages, (in the form of facts, data, information or images), which contains a purpose or meaning from sender to the recipient involving the process of meaning to power, authority, public life, government, state, conflict and conflict resolution, policy, decision making, and distribution or allocation. One function of political communication is as political information, namely the delivery of messages related to politics such as vision, mission, goals, targets or policies of both political parties and other political actors. Through political communication, information or messages conveyed by sources or senders (both political parties and other political actors) can be known, i.e. known or absorbed by the recipients (constituents or voters). Through this writing it can be seen that the role of political communication in respond to social conflict potential in society based on government policy. In the end community participation is expected so that the conflict potential becomes small or even disappears.
\end{abstract}

Keywords-Role of Political Communication, Social Conflict Potential, Government Policy

\section{INTRODUCTION}

Indonesia has always been colored by social and political conflicts. Social conflicts are inherent in life community. Part of the conflict in an unrelated society or no group that seeks to relate to politics is generally known as social conflict. On the other hand, there are social conflicts brought about or associated with power. Conflict directed or linked to power is known as a political conflict. To be a political conflict needs a social process that leads to the political process. Social and political conflicts can lead to violence. Social and political violence can occur as a result of the problems that cannot be resolved by the conflicting parties even through other parties are difficult to find solution, that the more difficult problem to solve will be more dissolve between the conflicting parties and increasingly open the possibility for the start of violence and violence widespread [1].

Conflict is an unpleasant situation for those who experience. This happens when resources related to the needs of society are limited. Theoretically, conflict is understood as a conflict between two parties and each of them seeks to preserve their life, existence, and principle. The conflicts within the community are grouped into categories: (1) personal conflict, (2) racial conflict, (3) political conflict, (4) interclass's conflict, (5) intergroup conflicts, (6) international conflicts and (7) mass-based conflicts.

In Indonesia, several cause of conflicts have occured, among others: (1) differences of someone's principle and senses are sharper that result clashing, (2) the fast growing of social changes in society resulting disorganization and principle differences about the reorganization of the new value system, (3) cultural differences that affect individual thought patterns and behaviors within the cultural group. This leads to clashes of groups, (4) clashes between the interests of both individuals and groups, for example economic, social, political, order and security interests, (5) economic issues such as fuel shortages, (6) weak leadership (7) injustices felt by some or all groups of people, (8) the low level of law enforcement, (9) theorizing traditional values that promote harmony and togetherness, (10) history of the past government operations, especially through armed forces.

In East Java, there are several conflicts that have occurred. In 2012-2013, the governments of Blitar and Kediri regency seized the Mount Kelud. District Government ofBlitar was preparing a claim against the decree of East Java Governor Soekarwo on the status of Mount Kelud which was set to 
belong to Kediri Regency. Meanwhile, Sidoarjo regency also has a number of social conflict issues, e.g. conflict among Lapindo mudflow victims, resident conflict in Tambakrejo Tambaksawah Waru Subdistrict and labor demo. In Surabaya, conflicts that occur include labor demos, handling land issues in Sukolilo and the problem of Dolly closing. In Sampang regency conflict that occurs is a conflict between difference of Muslims which are Sunni and Syiah.

In accordance with Law Number 7 Year 2012 on the Handling of Social Conflict, the government and law enforcement are required to carry out efforts to handle social conflicts starting from conflict prevention, conflict cessation, and so on. Considering the various backgrounds above, it is necessary to study the identification of potential social conflict based on Government policy in East Java (Case study in Sampang Regency, Kediri Regency, Blitar Regency, Sidoarjo Regency and Surabaya City) [2].

In this era especially in the period of openness that occurs in society, mass media has big influence. In this context the mass media becomes very beneficial for political communication. At least, the mass media has five functions that can be used as political communicator to realize the goal. The first function is the information function. Mass media has always been a source of information in various impressions or political events that occur in various parts of the planet including the activities of political actors with attitudes and political behavior attached to the actors. As a function of information mass media focuses more on the News elements that effect politically. The second function is the participation function. This indicates that every element of News must be able to generate community participation in supporting all government policies as long as the policy is related to the public interest. The third function is socialization and political education. This function is to improve the quality of community referrals in accepting and maintaining an ongoing value or political system. Both forms of this activity are a learning process that lasts for a long time. The fourth function is to develop a political culture called politicization function. This function is a determinant function of other functions, because the function of the political culture is to form a pattern of behavior that gives the dominant color to the character of a family. The fifth function is the integrity of the nation. This function is an absolute requirement for the life of the state in achieving the purpose [3].

For this reason, this research is about to discuss the following questions:

1. How is the model of completion in anticipating the potential of social conflict based on Government policy in East Java?

2. Why is the political communication needed in anticipating potential social conflict based on Government policy in East Java?

\section{THEORETICAL FRAMEWORK}

\section{A. Social conflict: definition, impact and form of completion.}

Conflict can be seen as a struggle between individuals or groups to win something they both want to achieve. The defeat or destruction of the rival is viewed by the person concerned as a major goal to win the goal to be achieved. The goal of conflict is the destruction of the rival, hence, the goal of winning something to be achieved is often not as important as the desire to destroy the other side. Social conflicts that are an extension of individual conflict usually manifested in the form of physical conflict or war of two or more groups, which usually occur in recurring circumstances [2].

If following the Dahrendorf model, it can be hypothetically known that in every society there are potential conflicts because every citizen will have an interest that must be fulfilled, for which will have to sacrifice the interests of other citizens. Attempts to fulfill the interests of a person sacrificing another's interests may constitute a potential conflict, if it is done without following the rules of the game that are considered fair and civilized. If in the community there are rules of the game that are recognized by the citizens as fair and civilized, then the potentials of conflict will transform themselves in various forms of competition. Thus, the potential for conflict to grow and develop at a time in the relationships between individuals arises and develops and the firmness of feelings that one of the perpetrators will have arbitrary treatment and unjust and barbaric acts suffered caused by the actions of the rival.

This social conflict has many impacts. From the sociocultural aspect, this conflict has negative consequences, among others are (a) reinforcing stereotypes, (b) clarifying social distance, (c) changing individual personalities, (d) dominance (if the power of disputing parties is unbalanced) (e) the subordination of either party to domination. In addition to the negative consequences, the positive outcomes are (a) strengthening solidarity of the internal group, (b) the opposition of two camps raises sympathy from other people/groups, (c) the accommodation (if the strength of the rival is balanced). Similarly in the legal aspects, conflict can result (a) human rights violations, (b) land ownership issues. Besides, economically and spatially, conflicts can result in (a) the lost employment, (b) the emerging of job opportunities, (c) the slum problems. In terms of population aspect, the conflict resulted in (a) population movement (due to prolonged conflict), (b) other social problems such as health, security, employment and so on. Meanwhile, from the government side, because of the displacement that impact on congestion and congestion, public services also have problems.

Theoretically to prevent a deeper negative impact there are several models of settlement. First, conciliation is an attempt to pay attention to the wishes of the disputing parties to reach an agreement. The second is mediation as a conflict control involving third parties as advisers in conflict resolution. Third parties have no right to decide unilaterally. The third is arbitration. In the arbitration process, a third party as mediator. Third parties are elected by both warring parties and higher institution [2].

\section{B. Political Communication}

Political communication is a process of transferring messages, (in the form of facts, data, information or images), which contains a purpose or meaning from the sender to the recipient that involves the process of meaning to power, 
authority, public life, government, conflict and conflict resolution, policy, decision making, and distribution or allocation.

Political communication is the process of delivering political messages from communicators to communicants. The function of political communication among others is as a function of information, educational function, instructional function, function of persuasion and entertainment. While the political communication models are Lasswel communication model, interaction communication model, and transactional communication model. Meanwhile, political communicators include politicians, professionals, activists, community leaders, tongue-mover and democratic elite. In this case, political communicators play an important role in conveying information and messages to be conveyed [4].

Michael Rush and Phillip Althoff define political communication as a process whereby relevant political information is passed from one part of the political system to another, and between social systems and political systems [5].

\section{METHODS}

This study used a qualitative approach using quantitative data support and triangulation materials. Ethnographic model is as an option in this type of qualitative research. This model is an attempt to understand the community (learning from people, but not just with a symbolic interaction footing as understood by Spradley) and requires the use of participant observation [6].

Particularly, in the public policy making, it developed a concise procedure is called Rapid Assessment Procedures. The way is, some of the data coming from statistical data is analyzed interpretatively, and the rest is collected through life history and FGD [7]. This study attempts to understand the conflicts that occurred in five districts in East Java (Surabaya, Sidoarjo, Sampang, Kediri and Blitar).

TABLE 1 RESEARCH SUBJECTS

\begin{tabular}{|l|l|l|}
\hline No & \multicolumn{1}{|c|}{ Criteria } & \multicolumn{1}{|c|}{ Informant } \\
\hline 1. & Local bureaucracy & $\sqrt{ }$ \\
\hline 2. & Institution of Order and Security & $\sqrt{ }$ \\
\hline \multirow{3}{*}{3.} & Local Elites & $\sqrt{ }$ \\
\cline { 2 - 3 } & Religious Local Elite & $\sqrt{ }$ \\
\cline { 2 - 3 } & Non-Religious Local Elite & $\sqrt{ }$ \\
\hline \multirow{2}{*}{4.} & Society & $\sqrt{ }$ \\
\hline & Non-Religious informal Leader & $\sqrt{ }$ \\
\hline & Householder & $\sqrt{ }$ \\
\hline & Youth & $\sqrt{ }$ \\
\hline 5. & Supra-local Structure & \\
\hline
\end{tabular}

\section{RESULTS AND DISCUSSION}

\section{A. The Model of Resolution in anticipating social conflict potential based on Government policy in East Java.}

From the research results that have been done by Setyowati, the model of social conflict resolution is obtained. Namely, the case of Syiah-Sunni in Sampang Madura was the result of the government both at the level of the Bupati and the government of East Java province which was weak in monitoring the potential conflict between people caused by religious differences. Furthermore, the policies issued by the regents of Sampang and the provincial government to handle Sunni-Syiah are the relocation of Syiah out of the Madura. This relocation policy has made the Syiah disciples feel discriminated by the district and provincial [2].

The Syiah-Sunni conflict leads to the Syiah community's relocation policy. If referring to the view of V. K. Korostelina, it appears that the government continues to reconcile the two disputing camps by adapting the reconciliation approach. Reconciliation means an attempt to observe the wishes of the disputing parties to reach an agreement. This reconciliation process was pursued after learning that the Syiah-Sunni case is a conflict that belongs to the question of politic identity. Korostelina argues that the formation of identity is the result of identification involving the process of socialization, shared values, beliefs, expectations, norms, and so on. Identity is a structure with complex interrelation between different subidentities [4].

Specifically, the above understanding associated with the process of handling the Sunni-Syia conflict shows that there is a close relationship between identity and conflict that results in the emergence of prejudices between groups. Prejudice is measured using standardized scales containing statements about group attributes, feelings toward groups, and support for policies that affect them.

In the daily life, conflict between the dominant versus minority groups into long conflict also triggered on Madurese society culture which has the view of obedience to the figure of Kyai, shown in the form of fanaticism to the teacher which is high enough. As a result, it can be indicated that the SunniSyiah conflict occurred proceeded by the different views experienced by religious leaders who later diverged this view followed by his followers. Thus, if there is a view that is not in line or not in accordance with what is taught by the elders and the teachers in Madura then it is called perverted teaching, the unbeliever and different, so it should be straightened out. Fanaticism to the Kyai is then causing the hostilities between identity groups triggered by prejudices. Prejudice itself is a tool for maintaining identity groups [2].

The Case of Dolly Closing Surabaya. Basically, the closing Dolly localization initiated by East Java Governor, and followed up by the Mayor of Surabaya had been approved by all parties, including citizens around Dolly localization. The trigger of conflict before and during the execution process, according to residents around Dolly, was the less socialization by Government of Surabaya City about the Dolly closing regularly and qualified related to the handling of the economic life after its closing, according to residents, it was never done.

The data taken from the research subjects revealed that the people around Dolly localization actually stated the approval for the closing of localization activity. They realize that prostitution can cause moral damage to the generation of the children of the nation. However, they expressed objection to the closure of Dolly due to the lack of socialization from the municipal government about the closing schedule and extension of alternative jobs they deserve. Until the closing of the Dolly by security forces led to clashes between police and 
residents, the Mayor had never socialized it to the residents. It was then led to the closing policy of Dolly rejected by the citizens.

According to residents, the policy of closing Dolly causes the death of the economy of citizens. The death of this citizen's economy is affected on the increasing of crime. This caused the increasing of unemployed. As a result of the lack of socialization in the form of closing schedules and guidance of the amount of compensation for the existing business in Dolly localization area, the victims of Dolly closing do not trust the Mayor any longer. They suspected that the Mayor listened more to the certain groups to close Dolly. Conciliation needs to be done beside the more intense political socialization [2].

The Relocation and Compensation Policy of Lapindo Mudflow Victims. The responsibility for the Lapindo mudflow event since 2006 has not been determined yet, even PT. Minarak Lapindo Brantas as the owner of the mineral drilling project cannot be blamed after the East Java Police stopped the investigation in August 2009. The plenary session of the House of Representatives in September 2009 stipulated that the cause of the Lapindo was the spurt natural disaster, not human error. From these two decisions, the government's position is legally responsible for overcoming the problems of relocation and compensation for the victims of Lapindo Mudflow. The government is responsible marked by the release of the budget of at least Rp. 500 billion since 2007 .

In March 2014 the Constitutional Court (MK) made a relief that was enough to grant the lawsuit of the victims of Lapindo mudflow victims totaling six land owners and buildings located in the area of the Map area affected by the Lapindo mudflow. Based on the above illustration, it can be concluded that the ideal arbitration model is chosen in dealing with the Lapindo mud disaster compensation policy conflict after the conflict resolution model is not reached. This fact was marked by the fact that before the decision of the House of Representatives plenary meeting which stated that Lapindo mudflow is a natural disaster, the government seeks to position itself as a conciliation agent and as a party that seeks to pay attention to the wishes of the disputing parties to reach an agreement. However, this effort was considered unsuccessful after the two sides of the Lapindo mudflow victims with PT. Minarak Lapindo did not find an agreement on who is most responsible. From both sides, the mutual accusation is as the perpetrator. Lapindo mud victim party accused PT. Minarak Lapindo Brantas is the main perpetrator of the mineral drilling which is fatal. However, PT. Minarak Lapindo Brantas rejected the accusation by arguing that the mudflow is a natural disaster phenomenon.

Seeing such feud the government seemed helpless so the government took a stand to ask opinions to members of the House of Representatives for questioning and verdict about the decision of Lapindo mudflow status whether caused by human error or natural disaster. After getting a proposal from the government, members of the House held a plenary session resulting in the fact that Lapindo mudflow is a natural disaster phenomenon. Seeing this verdict, the most responsible one is the state. Since this ruling came into force in 2007 the country has spent at least 500 billion to deal with the Lapindo mudflow problem.

Finally there are some victims of Lapindo mudflow filed a material test on the handling of Lapindo mud victims to the Court, and grant material test of Lapindo Sidoarjo mudflow victims in the area of the map affected. Taking legal action by applying the material test to the Constitutional Court conducted by representatives of Lapindo mudflow victims proves that the arbitration process is more ideal than the mediation process done by the government because the mediation model conducted by the government has not yielded much result and slow in dealing with Lapindo mudflow conflict [2].

The Disputation Case of Mount Kelud by Blitar Regency and Kediri Government. Basically, to overcome this problem the mediation effort had been done by the provincial government of East Java by inviting the two sides of the regency to sit together discussing the Governor of East Java Decree No. 188/113/KPTS/013/2012 February 28, 2012 which stated that Mount Kelud belonged legally to Kediri regency. But this effort does not meet the point, because the mediation process is not well responded by Blitar regency and not attending a number of mediation meetings initiated by East Java Provincial Government. Meanwhile, District Governer of Blitar actually chooses how to solve this dispute by looking for other agencies/institutions that are considered able to solve this problem namely the High Court of the State or PTUN.

The legal steps were taken because the regency of Blitar assessed that East Java provincial government defended more to Kediri regency. Meanwhile, East Java provincial government invites the legal efforts made by Blitar regency. It succeeded when the PTUN declared Mount Kelud in the status quo or not owned by anyone during the process of investigation and re-identification of territorial borders by the state.

Referring to Dahrendorf, the dispute between Blitar and Kediri regency stems from the mutual show of authority power. For him, the authority attached to the actor will subordinate to the rival group. Likewise, the super ordinate position will retain the status quo of a conflict. In this case, the actors who possess the important authority are the Regent of Blitar and Kediri. Furthermore, their position becomes an important position in the determination of management strategies and the defense of important assets that can support the inclusion of regional PAD areas such as Mount Kelud.

The Kelud ownership dispute certainly brings negative impacts on some aspects such as in the legal aspect, i.e. the conflict can result in land ownership issues. In economics and spatial aspects, conflicts can result in (a) lost employment and local revenues between the two regencies. In terms of population aspect, the conflict resulted in (a) population movements (due to prolonged conflict), (b) other social problems such as security, employment and so on [2].

Some models of social conflict resolution that may occur are mediation, conciliation/reconciliation or arbitration. All of these are according to the type of conflict that occurred and the location where the conflict arose. Everything will be minimized if using effective political communication. 


\section{B. The role of political communication in anticipating potential social conflict based on Government policy in East Java}

Several cases of social conflicts which occur in several cities in East Java above are caused by the exit of several policies that have caused the problem to be protracted. Some forgotten things in the process of policy delivery are the neglected role of political communication. Political communication is actually a process of delivering messages (information) related to the politics of communicators to communicants within the society (culture) of Indonesia. The sphere of Indonesian cultural society also means in the (sphere/environment) political system of Indonesia. Distinguishing communications in general and political communication lies in political communication focusing on political issues. While communications generally discussing communication in general, not limited to political problems.

Today is the third era of political communication where people are more believe in the television news or other social media that is not necessarily the truth. Effective political communication is necessary. Political communication in many democracies appears to have passed through three successive phases in the postwar period. Each has pivoted on a distinctive organizing principle, although other influences have prevailed as well. In Age 1, the political system was regarded as the prime source of initiatives and debate for social reform, and much political communication was subordinate to the relatively strong and stable political institutions and beliefs.

In Age 2, a new era dawned in the 1960s when the limitedchannel nationwide television became the dominant medium of political communication. To cope with the demands of a new medium, its larger audience, and more mobile electorate, the parties have to work harder and learn new tricks. They accordingly adopted an array of tactics to get into the news, shape the media agenda, and project a preplanned "line" in press conferences, briefings, interviews, and broadcast discussions.

In Age 3, this still emerging phase is marked by the proliferation of the main means of communication, media abundance, ubiquity, reach, and celerity. Television in particular, once a concentrated communications outlet of a few channels for politicians to court, has become or is becoming an extensively elaborated journalistic medium, hosting news flashes and inserts, formed bulletins, a wide range of public affairs formats, and 24-hour news services. Communication abundance not only embraces the multiplication of television channels and radio stations, but it also reflects the proliferation of communication equipment in people's homes; multiple television and radio sets, video recorders, compact disc players, video games, and camcorders. Beyond mass media, political news, information, and ideas can be circulated via the computer. New patterns and adaptations ensue for all involved in the political communication process. In gist, it changes how people receive politics which has been studied so far. When something happens, the politicians are expected to tell the media what they are going to do about it well before they can be fully informed themselves. For journalists, the news cycle has accelerated, since more outlets combined with increased competition across them. This is more complex than its predecessors, molded more by conflicting cross currents than by a dominant tendency. Political communication during it is likely to be reshaped by trends, not all in harmony with each other [8].

The Importance of Political Communication will be increasingly important if we listen and track the function of political communication as proposed by Mc. Nair and Hedebro in Cangara [9] which includes: a. Providing information to the public about efforts made by political institutions and in relation to government and society; b. To socialize the policies, programs and objectives of political institutions; c. Provide motivation to politicians, functionaries and party supporters; $d$. Being a platform that can accommodate the ideas of the community, so it becomes the talk in the form of public opinion; e. Educate the community by providing information, socializing about the ways of elections and the exercise of their rights as voters; f. Become public entertainments as "democracy party" featuring campaigners, artists, and political commentators or observers; g. Fostering integration by enhancing a sense of nationalism in order to avoid conflicts and threats of separatist action threatening national unity; h. Create a climate of change by altering power structures through information to seek public support for the reform movement and democratization; i. Increase the political activities of the community through newscasts, agenda setting, as well as comment on political commentary; $\mathrm{j}$. Become a watch dog or guard dog in helping to create good governance that is transparency and accountability.

\section{CONCLUSION}

Within the framework of the social dimensions of society, it will always be related to politics. Politics and society or conversely are two sides of the coin, i.e. although they differ from their respective press points, yet they cannot be separated in their social realities, both in the short and long-term, both in the individual and group spheres. This is a relationship between society and politics, so in discussing the potential for social conflict in the community it will always be related.

In everyday life human beings can not be separated from what is so-called conflict. Whether realized or not, there is always cooperation and competition therein. Therefore, good communication process should always be put forward. Do not let miscommunication happen in politics because the impact will be extraordinary. Effective political communication is necessary to do so it will not encourage the rise of potential social conflicts that threaten. Various policies issued by the government should always be communicated first and done according to good and correct procedures, so hopefully there will be no potential social conflict activities within the community.

\section{ACKNOWLEDGMENT}

The authors would like to thank the Balitbang of East Java Province that funded this research in 2014 and Unesa Surabaya as the organizer of this international seminar in 2017. 


\section{REFERENCES}

[1] Tukina, "Critical Analysis of Political Communication on Conflicts in Indonesia.," Bina Nusant. J., 2013.

[2] F. S. S. and M. L. Rr Nanik Setyowati, "Government Policy Dilemma in East Java: State, Society and Company," Int. J. Humanit. Soc. Sci., vol. . 5, No. 4.

[3] R. Tabroni, "Ethics of Political Communication in the Mass Media Scope," J. Commun. Sci., vol. Vol. 10, N, 2012.

[4] K. V Korostelina, Social Identity and Conflict. Structures, Dynamics, and Implication. New York and Hampshire, London: Palgrave Macmillan, 2007.

[5] M. R. and P. Althoff, Introduction to Political Socioogy. Jakarta: Raja
Grafindo Persada Publisher, 1997.

[6] P. A. and M. Hammersley, Etnography. Principles in practice, Third Edit. London and New York: Routledge, Taylor \& Francis Group., 2007.

[7] S. C. . S. and E. Hurtado., Rapid Assessment Procedures for Nutrition and Primary Health Care. Tokyo: United Nations University., 1987.

[8] J. G. B. and D. Kavanagh, "The Third Age of Political Communication: Influences and Features," Polit. Commun., 1999.

[9] H. Cangara, Introduction to Communication Science. Jakarta: Raja Grafindo Persada Publisher, 2007. 